\title{
Punishing Communist Rights Abuses
}

\section{Myroslava Antonovych}

The problem of correlating law, politics, and justice inevitably arises in periods of political change. According to Ruti Teitel, a dilemma arises over the relationship between the rule of law and the problem of successor justice. To what extent does bringing the old regime to trial imply an inherent conflict between predecessor and successor visions of justice? In light of this conflict, is such criminal justice compatible with the rule of law? The dilemma raised by successor criminal justice leads to broader questions about the law's role in the transformation to the liberal state. Many scholars claim that in transitional periods the rule-of-law principle takes precedence over the prior regime's laws.

According to Neil J. Kritz, there are two ways of coping with the legacy of the past: take criminal sanctions against the leaders of the ousted regime or their henchmen for the abuses they inflicted upon the nation, or impose non-criminal sanctions that most often mean purging from the public sector those who served the repressive regime. Criminal prosecution of the perpetrators was the typical policy toward collaborators in the Western European countries occupied by the Nazis during World War II. In contrast to this strategy, in postcommunist Central and East European states, lustration - or the disqualification of former elites, secret police agents and informers, and civil servants - was used to impose accountability.

Arguments for and against prosecution are often diametrically opposed. Some claim that prosecuting former regime crimes strengthens fragile democracies, which need legitimacy as they foster respect for democratic institutions and deepen democratic traditions. But this is countered by arguments that prosecutions can destabilize an immature democracy, jeopardizing the democratic transition and weakening the new regime's legitimacy. On the one hand, it is claimed that impunity precludes reconciliation, while on the other hand, it is suggested that criminal prosecutions may have the same effect. Some scholars and politicians claim, for the sake of a nation's reconciliation, that the past must be left behind and the prior regime's sins must be forgiven.

But punishing grave human rights violations by a prior regime may be necessary to prevent their recurrence and to repair the damage they caused. As fairly stated by the German writer Jurgen Fuchs, "[i]f we do not solve this problem in a definite way, it will haunt us as Nazism did. We did not denazify ourselves, and this weighed on us for years." Impunity, moreover, allows people to move into leadership positions where they become liable to blackmail through the threat of exposure of their involvement in the former regime. And it can hardly be denied that the successor government must ensure that justice be done, first of all as a moral obligation to the victims of the repressive system. 
$\mathrm{T}$ he postcommunist states of Central and Eastern Europe, while having experienced similar legacies, nevertheless took different approaches to past human rights abuses. In the The Third Wave, Samuel Huntington argues that the process of democratization can be seen in the interplay between governing and opposition groups along a continuum that produces three types of transition. Transformation occurs when elites take the initiative to bring about democracy. Replacement happens when the initiative rests with the opposition. And transplacement occurs when democratization results from joint action by both government and opposition. According to Huntington, Hungary and Bulgaria were transformations, Poland and Czechoslovakia transplacements, and East Germany was a case of replacement. These differences influenced the way each of these nations came to terms with their past.

In 1991, the Czech and Slovak Federal Republic (CSFR) adopted the Screening (Lustration) Law which banned members of the National Security Corps; residents, agents, and collaborators of the State Security; and party officials from exercising functions in the state administration, in the Czechoslovak Army, and elsewhere, for a period of five years ending on January 30, 1996. Later, Parliament extended the law to the year 2000, overriding a veto by President Vaclav Havel. This law might affect 300,000 people. In response to the complaint lodged by the Trade Union Association of Bohemia, Moravia and Slovakia, and by the Czech and Slovak Confederation of Trade Unions, the International Labor Organization invited the Government of the CSFR to refer the case to the Czech and Slovak Constitutional Court. It sought a ruling on whether the law violated Convention No. 111, which seeks to protect against discrimination based on political opinions. In November 1992 the Court found several articles of the Screening Law in violation of the Bill of Basic Rights and Freedoms, and declared illegal the provision targeting "potential candidates for collaboration."

After Czechoslovakia was divided into two countries, the Czech Republic continued lustration proceedings under the same law. By August 1993, 210,000 people had been screened, and some had been banned from official positions. But the overall impact of the Czechoslovak Screening Act is difficult to judge, since in its original form it lasted only one year. In 1993, the Act on the Illegality of the Communist Regime and Resistance to It was adopted in the Czech Republic. It declared the previous, communist regime (including the Czechoslovakian Communist Party), which governed from 25 February 1948 to 17 November 1989 , to be criminal, illegal, and contemptible. In response to a petition filed by various deputies of the Czech Parliament requesting the Act's nullification, the Constitutional Court nevertheless confirmed the illegitimacy of the political regime from 1948 to 1989.

According to Jan Obrman, the law declaring the Communist Party's illegitimacy could provide the legal basis for liquidating the party in the future, similar to the legislation that outlawed both the National Socialist German Workers Party and the propagation of Nazi ideology in Germany. Besides rejecting these ideologies, such laws provide moral satisfaction for the victims. Czech President Havel has stressed the law's importance: "[T] hrough this law, the freely elected parliament is telling all victims of communism that society values them and that they deserve respect." Meanwhile, in Slovakia, the new government opposed the 
Lustration Law, and in January 1994 petitioned the Constitutional Court to overturn it. While the Court rejected the petition, the law was never invoked, and then it expired at the end of 1996. In February 1996, the Slovak National Council adopted a new law declaring the former communist regime "immoral" and "illegal," but this has yet to be reviewed by the Constitutional Court.

$\mathrm{H}$ ungary was the first among the former communist countries to adopt a law that could bring criminal proceedings against former communist officials. This resulted from the November 4, 1991 Law Concerning the Prosecutability of Offenses Committed between December 21, 1944 and May 2, 1990, introduced by two deputies of the Hungarian Democratic Forum, Peter Takacs and Zsolt Zetenyi. The bill called for the suspension of the statute of limitations for cases of treason, premeditated murder, and aggravated assault leading to death which had been committed between December 21, 1944 and May 2, 1990 where, for political reasons, prosecutions had not previously been possible.

Those favoring the law claimed that the victims of communist crimes would otherwise have to live alongside torturers and murderers, which would distort people's sense of right and wrong. The trials would not pursue average citizens who might have become Communist Party members to get or to keep their jobs but rather people who were directly involved in torturing or killing innocent individuals. Yet, a unanimous Constitutional Court overturned the law. It justified its decision by adhering to the rule of law: "Legal certainty based on objective and formal principles takes precedence over justice which is partial and subjective at all times."

Still, this was not the end of the story. In March 1993, the Hungarian Parliament adopted a law on Procedures Concerning Certain Crimes Committed during the 1956 Revolution, based on international instruments such as the Geneva Conventions Relative to the Treatment of Civilians in the Time of War and Relative to the Treatment of Prisoners of War of 1949 and on the New York Convention on the Non-Applicability of Statutory Limitations to War Crimes and Crimes against Humanity of 1968. In its pre-promulgation review, the Court upheld the law based on Article 7 of the Hungarian Constitution: "The legal system of Hungary shall respect the universally accepted rules of international law, and shall ensure, furthermore, the accord between the obligations assumed under international and domestic law." The Act was endorsed for ensuring the enforcement of "universally accepted rules of international law."

As in other Central European states, a screening law was also adopted in Hungary. The Law on the Background Checks to be Conducted on Individuals Holding Certain Important Positions (Law No. 23 of March 8, 1994). According to Edith Oltay, the purging of former agents from high-ranking state positions was necessary not only morally but also to prevent blackmail. It was viewed as helping Hungary come to terms with its past. The law subjected approximately 12,000 officials to a screening process by at least two committees each consisting of three professional judges, which were to complete their work between July 1, 1994 and June 30, 2000. Information about public officials will be accessible to the public 30 years after the panel's ruling.

After the Constitutional Court struck down several provisions of the 1994 law, Parliament enacted a new law in July 1996, which stipulates that all persons born 
before February 14, 1972 must be screened before taking an oath before the Parliament or the President. After two screening committees examined the records of approximately 600 officials, several deputies were accused of having worked as secret agents.

$\mathrm{T}$ he decommunization of East Germany, in contrast to other Central European states which dealt with their former regime crimes domestically, has been greatly influenced by West German laws and courts. In response to the decisions of the Commission on Security and Cooperation in Europe on Human Rights and Democratization in Unified Germany (CSCEHRDUG), some East Germans found the process unsatisfying, claiming the system had largely failed to prosecute the leaders of the corrupt and immoral East German regime.

One of the primary goals of the East German decommunization process was the historical, political, and juridical reappraisal of State Security Service (Stasi) activities. On November 15, 1991, the united German parliament adopted a law permitting citizens to see their files and a month later, on December 20, the Act Concerning the Records of the State Security Service of the Former German Democratic Republic ("Stasi Records Act") was approved. On January 2, 1992, the files were opened and anyone could obtain the contents of his or her Stasi file. These checks have resulted in the dismissal of thousands of judges, police officers, schoolteachers, and other public employees in eastern Germany who once informed for the Stasi.

But according to Thomas R. Ronchon, it was hard to find a legal basis for prosecuting Stasi activities. Unlike the case of the genocidal policies of the Nazi regime, the claim could not be made that telling the secret police about the activities of a friend, neighbor, or colleague was a violation of international law. West German law made it punishable for East German agents to spy on West or East German citizens, but the five-year West German statute of limitations rendered prosecution under those terms nearly impossible.

As a consequence, the government was obliged to prosecute officials of the former regime for transgressions of East German law, rather than questioning the morality of those laws in the first place. The moral consequences of opening the Stasi files were quite unpredictable. As the report of the CSCEHRDUG suggests, "[f]rom well-respected dissident Vera Wollenberger — who learned with horror that her own husband had betrayed her, to Gerhard Riege - a member of the Bonn parliament who hanged himself after it was reported that he had been a Stasi informer, countless lives have been profoundly affected." And additional lives have been affected by Stasi informers. Moreover, as Joachim Gauck points out, "[j] ust imagine what would have happened if the files had been kept secret: not only would it have been impossible to create a climate of trust, but the files could have been used to threaten and blackmail people."

There were efforts in Germany to prosecute the former President Erich Honecker and five other high-ranking Communist Party officials. The charges were based on three grounds: first, that Honecker exceeded his power under East German law; second, that he broke international laws, including the International Covenant on Civil and Political Rights; and third, that he violated basic human rights. By January 1993, however, a terminally ill Honecker was relieved from the trial and the Berlin Constitutional Court lifted the arrest order. 
$\mathrm{I}^{\mathrm{n}}$ n Albania, the 1992 Law on Political Parties prohibited "any party or organization with an antinational, chauvinistic, racist, totalitarian, Fascist, Stalinist, 'Enverist' or Communist, or Marxist-Leninist character, or any political party with an ethnic or religious basis." Between 1992 and 1994, the government brought charges against more than 70 former communist officials. In December 1993, ten senior officials were each fined the equivalent of U.S.\$60,000 and sentenced to prison. An important Law on Genocide and Crimes against Humanity Committed during the Communist Regime for Political, Ideological, and Religious Motives ("Genocide Law") was adopted in 1995. It prohibits people with ties to the regime prior to March 1991 from holding selected positions in the government, parliament, judiciary, or mass media until the year 2002.

In January 1996, Albania's Constitutional Court upheld most provisions of the Genocide Law as well as of the 1995 Law on the Verification of the Moral Character of Officials and Other Persons Connected with the Defense of the Democratic State ("Lustration Law"). As a result of the screening process, 139 candidates were banned from participating in the 1996 parliamentary elections. Democracy turned out to be very weak in Albania, however, and despite the screening, the Socialist Party was returned to power in the June 1997 elections.

Bulgaria went a different route, and the Union of Democratic Forces regained power in the 1997 elections. A law that makes mandatory the opening of all files of members of high government officials and gives them one month to admit their past activities was adopted in July 1997. It was upheld by the Bulgarian Constitutional Court. But the Court did support the claim made by opposition party deputies that the law could jeopardize the ability of the president, vice president, and Constitutional Court members to function, and ruled that the files of individuals in those positions should not be opened.

With the exception of the Baltic states, where transition started as replacement and changed into transplacement, all the rest of the former Soviet Union republics combined elements of two or more transitions. This was launched by the policies of perestroika (economic reconstruction) and glasnost (openness) established by the Communist Party of the former Soviet Union. The changes were continued by opposition democratic forces in almost all of the former Soviet Union republics after the failed coup organized by a group of Communist Party, military, and KGB officials. For example, the Presidium of the Verkhovna Rada (Parliament) of Ukraine issued a Decree (Ukaz) on the Temporary Suspension of the Activity of the Communist Party of Ukraine (August 26, 1991), having accused the Communist Party of participating in the coup. The Communist Party's property and financial assets were frozen and absorbed into the Verkhovna Rada's accounts pending a judicial investigation. Another Decree focused more specifically on the Ukrainian property held by the Communist Parties in both the Ukraine and the Soviet Union. The Ukrainian Constitutional Court has yet to examine the constitutionality of these decrees.

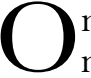
August 25, 1991, President Yeltsin issued decrees suspending the Communist Party of the Russian Federation and confiscating its assets, and on November 6, 1991 this was turned into an outright ban on the party. The Russian Constitutional Court examined these decrees. The result, according to 
Robert Sharlet, was a compromise that gave each side something, thus reflecting the disorderly, conflict-ridden politics of transition in Russia. The Court upheld the ban on the central Russian Communist Party but nevertheless affirmed its right to re-establish local branches.

Efforts to screen and purge former Communist Party officials and to adopt a lustration law failed in Russia. Moreover, some laws on state security were passed which complicated the implementation of lustration. One, the Law on Operative and Detective Activity, bans the exposure of witting agents of the KGB. Similarly, the Law on Federal Security Organs of the Russian Federation protects the covert status of persons cooperating with "state security organs." This practice, quite contrary to lustration, is unprecedented in other Central and East European States.

In Lithuania, the government issued a Decree Banning KGB Employees and Informers from Government Positions, and a Law on the Verification of Mandates of Those Deputies Accused of Consciously Collaborating with Special Services of Other States was also adopted. Even though these acts were implemented and the Temporary Commission of the Supreme Council investigated collaboration with the KGB and other secret services in Lithuania, absolute justice has not been reached. Many Lithuanian KGB files had been removed to Russia and not all of them were returned. Soon, replacement gave way to transplacement, and the Lithuanian Democratic Labour Party (LDLP) which succeeded the banned Communist Party — won the October 1992 parliamentary election.

To the credit of Algirdas Brazauskas, ex-president of Lithuania and LDLP leader, he did not run for president in 1997, believing that Lithuania deserved to have a president who had not been a past communist leader. A proliferation of such good will by former communists to promote transitional justice would be helpful for dealing with the past. In 1998, a new lustration law was passed. But the Lithuanian Prime Minister Gediminas Vagnorius and President Valdas Adamkus both believe the law is "dubious from the point of view of the constitution and international law."

Tn sum, while the Central and East European states have used various approaches to dealing with past human rights abuses, they also have much in common. Their practice confirms the international obligation to punish the human rights abuses committed by prior regimes. Most states have outlawed their Communist Parties and passed laws that screen and purge offenders from seeking public office. The communist regimes, which were extremely repressive before 1970, relied in the subsequent two decades on psychological violence through networks of secret service agents and collaborators. Hence, the postcommunist regimes have sought to purge these people, at least from official positions.

Lustration laws, which limit political participation, potentially clash with international human rights standards. But a state's obligation to deal with the past requires it to punish those guilty of other human rights abuses. The activities of Communist Party officials, agents, and collaborators victimized many innocent people. Moreover, lustration laws can be justified in a democratic society as being necessary to promoting the nation's national security and economic 
well-being. Former communist officials and secret service agents cannot be trusted to carry out democratic reforms.

Most Central and East European states condemned communist ideology, which they viewed as evil as fascism. In Le livre noir du communisme, a collection of respected analysts and historians has counted between 85 million and 100 million victims of communist regimes in the Soviet Union, Eastern Europe, China and Cambodia. These deaths, as Stephane Courtois argues in the book's introduction, deserve the appellation "crimes against humanity" - the term most closely associated with Nazi genocide. Yet, "while it is impossible to imagine any political party with the word 'Nazi' in its name operating successfully anywhere in Europe, communist and former communist parties continue to exist and thrive." Have we not learned from history?

\section{REGOMMENDED READINGS}

Applebaum, Anne. 1998. "Teflon Totalitarianism." Wall Street Fournal (January 16): 3.

Bassiouni, M. Cherif. 1997. "From Versailles to Rwanda in Seventy-Five Years: The Need to Establish a Permanent Criminal Court." Harvard Human Rights fournal 10: 11.

Courtois, Stephane et al. 1997. Le livre noir du communisme: crimes, terreur et repression. Paris: R. Laffont. Huntington, Samuel. 1991. The Third Wave. Norman, OK: University of Oklahoma Press.

Kritz, Neil J. (ed.), 1995. Transitional Justice: How Emerging Democracies Reckon with Former Regimes. Washington: United States Institute of Peace Press.

Mendez, Juan E. 1997. "Accountability for Past Abuses.” Human Rights Quarterly 19: 255.

Ronchon, Thomas R. 1992. "The Wall Within: Germans Cope with Unification.” in G. Post (ed.), German Unification, Problems and Prospects. Claremont, CA: Keck Center for International and Strategic Studies.

Teitel, Ruti. 1996. "Transitional Jurisprudence: The Role of Law in Political Transformation." Yale Law Foumal 106: 2009.

Myroslava Antonovych is Associate Professor of International Law with the Faculty of Law at the National University Kyiv-Mohyla Academy in the Ukraine. She has an LL.M. degree from McGill University in Canada and a Candidate of Sciences degree from the Kyiv Linguistic University in the Ukraine. Correspondence: Trostianetska St. 7b/134, Kyiv 253091, Ukraine. E-mail: mma@ukma. kiev.ua 
Copyright of Peace Review is the property of Carfax Publishing Company and its content may not be copied or emailed to multiple sites or posted to a listserv without the copyright holder's express written permission. However, users may print, download, or email articles for individual use. 